\title{
Cost and Economic Benefits of Postgraduate Education among Lecturers in Federal and State Universities in Edo and Delta States
}

\author{
Dr. Chukujindu Joyce Okafor ${ }^{1}$, Ven. Professor Mon. Nwadiani ${ }^{2}$ \\ ${ }^{I}$ Department of Education Faculty of Arts And Education Benson Idahosa University, Benin City. \\ ${ }^{2}$ Department of Educational Management University of Benin.
}

\begin{abstract}
This paper investigated the direct private cost and economic benefits (monetary) to investment in the postgraduate education of lecturers in Federal and state universities in Edo and Delta States. Descriptive survey method using ex-post designed was used. Study population was made up of two thousand, seven hundred and ninety - seven $(2,797)$ lecturers in the Federal and State universities in Edo and Delta states. Using purposive sampling technique method, 300 lecturers with either master's or doctoral degrees from Federal and State universities in Nigeria were sampled. A checklist on direct private cost and direct private economic benefit of masters' and doctoral degrees (DPCDEBMDE) - was used to solicit information on the direct private unit costs and economic benefits (salary and other monetary income) from postgraduate education. Data gathered were analysed using descriptive and econometric statistics. The results showed that: (a) there is a variation in the direct private cost of postgraduate education in course areas studied. (b) on economic (monetary) benefit to postgraduate education, the study also found that there are variations in economic benefits of postgraduate education of lecturers in federal and State universities in Edo and Delta states.. (c) the net present value and the profitability index of science based courses was highest followed by management sciences and Arts respectively. From the findings it was concluded that postgraduate education is a viable investment because it was profitable for all the courses studied. The results of this study have serious implications for individuals who may want to invest in this type of educational programme. And it is recommended that those who want to invest in postgraduate education should invest in sciences because it is highly profitable
\end{abstract}

Keywords: Cost, Economic benefit, Net present Value and Profitability Index, postgraduate education

\section{INTRODUCTION}

The economics of education has expanded considerably in scope over the last four and a half decades. The human capital theory remains central to any analysis of individual's behaviour regarding demand for education at any level. The modern analysis of the economics of education had its birth with Theodore Schultz's address to the American Economic Association in December 1960. That address introduced the notion that education can be regarded as an investment in human capital, an investment that is similar to investments in physical capital. The theory states that the individuals decide to invest in their own education, at the margin, just as firms decide to invest in new machinery. The investment in each case entails current costs, and yields future benefits. An internal rate of return to the investment can in each case be calculated (Psycharopoulos and Patrimos, 2004).

It is accepted as true that expenditure on training should be considered an investment (Psycharopoulos and Patrimos, 2004) since it is embarked on with a view to increasing income of the individual or the employer. Key to the theory of human capital is the concept that, gaining of more knowledge and skills raises the value of a person's human capital, thereby increasing their employability, income potential and productivity. In general terms, human capital stands for the investment people make in themselves that enhance their economic productivity. For example investment in postgraduate education, may involve a series of activities that influence future real income through the imbedding of resources in the individual who decides to pursue a postgraduate education.

According to Fagerlind and Saha (1997) human capital theory provides a basic justification for large public expenditure on education both in developing and developed nations. The theory is in agreement with the ideologies of democracy and liberal progression found in most Western societies. Its attraction is based upon the presumed economic return of investment in education both at the macro and micro levels. For individuals, such investment provides direct returns in the form of individual economic success and achievement. Educational investment according to Psacharopoulos and Woodhall (1997) should take into account certain criteria which are: direct economic returns to investment, in terms of the balance between the opportunity costs of resources and the expected future benefits; indirect economic returns, in terms of external benefits affecting other 
members of society; the private demand for education and other factors determining individual demand for education; the geographical and social distribution of educational opportunities; and the distribution of financial benefits and burdens of education.

Education plays a great and significant role in the economy of any nation. Thus expenditures on education constitute a form of investment. This improves individual's human capital and leads to greater output for society and enhanced earnings for the individual worker and allows them to reap pecuniary and non pecuniary returns and gives them opportunities for job mobility.

An individual's decision to invest in training is based upon an examination of costs and benefits of such an investment. Individuals are assumed to invest in training during an early period and receive returns to investment in later periods. While being trained, workers pay for their training by receiving wage which is lower than what they could have received elsewhere. Since training is thought to make workers more productive, workers collect the returns from their investment in later periods through higher marginal products and higher wages. Private training is financed by individuals, and the individual receives all the returns to this training. In contrast, individual and employers will share the cost and returns of specific training relating to the employee's job. A very important thing to note is that human capital investment provides more return in the long term. The theory of investment in human capital employs various Cost-Benefit Analysis models in project appraisal such as "internal rate of return" (IRR), Profitability Index (PI), Net Present Value (NPV) amongst others. However, this study employed Net Present Value and profitability Index method in the calculation of the cost and profitability of postgraduate education of lecturers in Federal and state universities in Edo and Delta States.

According to Afzal (2011) benefits to education are the reward of investing in education. This reward can be in the form of earnings and other social returns like honour, status, accommodating attitude, and so on.

Benefits to investments in higher education can be classified into three main categories: Private financial returns to education - acquiring education improves the earnings and/or employment prospects of individuals. Private non-financial returns to education - it includes improvements in individual's welfare that are not a part of measured earnings (e.g., easy access to highly paid jobs, better working environment and so on).

Social returns to education - acquiring education may have a benefit to other individuals of the society. It is over and above private returns to education. It would occur in the form of positive externalities of the education (Blundell, Dearden, Goodman and Reed 2000).

From the studies of Olakulehin and Panda (2012), Rugar, Ayodo and Agak (2010) and Psacharopulos and Patrinos (2002) Postgraduate education is seen as an investment which is believed to have both economic and non economic benefits. Is this assertion true of all investments in postgraduate education? If yes to what extent is the investment of individual resources in the postgraduate education justifiable to the individuals? Definitely, individuals will invest in a postgraduate education if such training will yield substantial returns to justify the investment. This paper therefore investigated the cost and the economic returns (monetary) to the postgraduate education among lecturers in Federal and State universities in Edo and Delta States.

It is on this premise that the following research questions were raised and answered.

\section{Research questions}

1 What is the direct private unit cost of postgraduate education among lecturers in Federal and state Universities in Edo and Delta States?

2 What is the direct private economic benefit of postgraduate education among lecturers in Federal and state Universities in Edo and Delta States?

3 Is there a variation in the economic benefits of postgraduate education of University lecturers in Edo and Delta States in Arts, Management science and science based courses?

\section{METHODOLOGY}

The lecturers in the federal and states universities in Edo and Delta states were two thousand, seven hundred and ninety seven $(2,797)$ (Main Report of Committee on needs Assessment of Nigerian Public Universities, 2012) and they were located in various disciplines in the federal and state universities in Edo and Delta states. They make up the population of the study.

The sample size was 300 lecturers with either master's or doctoral degrees from federal and state universities in Edo and Delta states of Nigeria. Purposive sampling technique method was used to obtain the respondents. The Lecturers were spread across Arts, Management Sciences and Science based courses.

A checklist on direct private cost and direct private economic benefit of masters' and doctoral degrees (DPCDEBMDE) - was used to elicit information on the direct private costs and economic benefits (salary and other monetary income) from postgraduate education. To determine the direct private unit cost, information on the approximate amount of money spent on the following items was sought for: tuition fees per annum, examination fees, registration fees, accommodation per annum, feeding per annum, books and stationery per 
annum, transport per annum; and other education related expenses per annum. This was analysed and the mean was calculated.

On the economic benefits, information on the approximate amount of salary and other sources of income was gathered from the checklist. This was also analysed and the mean was calculated.

Research questions were answered directly using the information gathered from the checklist. To determine Net Present Value (NPV) and the Profitability Index (PI) the costs of and benefits from postgraduate education were discounted to present values. This was done by assuming a rate of discount; (the government Treasury bill rate was used). To do this the following assumptions were made: -Discount rate 11\% (Treasury bill rate), Inflation rate $8 \%$ (single digit inflation rate by $(\mathrm{CBN}, 2013)$ and Time period of $15 y$ years. It is assumed that the individual is on one salary for 15years (a worst case scenario).

\section{RESULTS}

The results of the study are stated as follows:

\section{Question 1}

What is the direct private unit cost of postgraduate education of lecturers in Federal and state Universities in Edo and Delta States

Table 1 The direct private unit cost of postgraduate education of university lecturers in Edo and Delta States in Arts, Management sciences, and science based courses

\begin{tabular}{|c|c|c|c|}
\hline & ARTS \% & $\begin{array}{l}\text { MANAGEMENT } \\
\text { SCIENCES. }\end{array}$ & SCIENCES \\
\hline \multicolumn{4}{|l|}{ Cost items } \\
\hline Tuition & $\sharp 82,021$ & $₫ 83,161$ & $\sharp 57,508$ \\
\hline Registration & 20,505 & 9,595 & 13,070 \\
\hline Examination & 8,202 & 9,595 & 5,228 \\
\hline Accomodation & 49,213 & 31,984 & 49,666 \\
\hline Transportation & 49,213 & 41,580 & 36,596 \\
\hline Feeding & 110,729 & 54,374 & 54,894 \\
\hline Books \& stationeries & $90,223 \quad 22$ & $89,558 \quad 28$ & $\begin{array}{ll}44,438 & 17 \\
\end{array}$ \\
\hline Total & $\begin{array}{l}\text { N410,106 or } 41.37 \% \\
100\end{array}$ & $\begin{array}{l}\text { N319,849 or } 32.26 \% \\
100\end{array}$ & $N 261,399$ or $26.37 \% 100$ \\
\hline
\end{tabular}

Adapted from Nwadiani and Okafor (2015)

"The direct private unit cost for postgraduate education of lecturers in universities in Edo and Delta states as shown in Table 1, for Arts is $\$ 410,106$ (41.37\%); Management science is $\$ 319,849$ (32.26\%); and Sciences is $\$ 261,399$ (26.37\%). Arts based courses have the highest unit cost followed by Management Sciences with Science having the least direct private unit cost" (Nwadiani and Okafor 2015)

Question 2 What is the direct private economic benefit of postgraduate education among lecturers in Federal and state Universities in Edo and Delta States?

In determining the economic benefit (monetary) of postgraduate education of university lecturers in Edo and Delta states, the net present value and the profitability index were calculated. To do this however, some assumptions were made. A risk free interest rate of $11 \%$ was used, $8 \%$ inflation rate was assumed (CBN, 2013) and it was also assumed that the cash inflow of individuals for fifteen (15) years remained constant. This assumption is a worst case scenario. In real life salaries increase every year. Having these assumptions in mind, the Net Present Value (NPV) and Profitability Index (PI) of postgraduate education of university lecturers in Edo and Delta states with the E-view are presented in the Table 2.

Table 2: Net Present Value (Npv) Summary For All Courses

\begin{tabular}{|l|l|l|l|l|l|}
\hline $\begin{array}{l}\text { Years after } \\
\text { graduation }\end{array}$ & $\begin{array}{l}\text { Present Value } \\
\text { at } 11 \%\end{array}$ & $\begin{array}{l}\text { Cumulative Present } \\
\text { Value at 11\% }\end{array}$ & $\begin{array}{l}\text { Average Cash } \\
\text { inflow N }\end{array}$ & $\begin{array}{l}\text { Cumulative Present } \\
\text { Value of Cash inflow }\end{array}$ & $\begin{array}{l}\text { Cumulative Net Present } \\
\text { Value (NPV) }\end{array}$ \\
\hline 1 & 0.90 & 0.90 & $3,240,885$ & $2,916,797$ & 2,578116 \\
\hline 2 & 0.81 & 1.71 & $3,240,885$ & $5,541,913$ & 5,203232 \\
\hline 3 & 0.73 & 2.44 & $3,240,885$ & $7,907,759$ & 7569078 \\
\hline 4 & 0.66 & 3.10 & $3,240,885$ & $10,046,744$ & 9,708063 \\
\hline 5 & 0.59 & 3.69 & $3,240,885$ & $11,958,866$ & $11,620,185$ \\
\hline 6 & 0.53 & 4.22 & $3,240,885$ & $13,676,535$ & $13,337,854$ \\
\hline 7 & 0.48 & 4.70 & $3,240,885$ & $15,232,160$ & $14,893,479$ \\
\hline 8 & 0.43 & 5.13 & $3,240,885$ & $16,625,740$ & 16,287059 \\
\hline
\end{tabular}


Cost and Economic Benefits of Postgraduate Education Among Lecturers in Federal and State

\begin{tabular}{|l|l|l|l|l|l|}
\hline 9 & 0.39 & 5.52 & $3,240,885$ & $17,889,685$ & $17,551,004$ \\
\hline 10 & 0.35 & 5.87 & $3,240,885$ & $18,051,729$ & $17,713,048$ \\
\hline 11 & 0.32 & 6.19 & $3,240,885$ & $20,061,078$ & $19,722,397$ \\
\hline 12 & 0.29 & 6.48 & $3,240,885$ & $21,000,935$ & $20,662,254$ \\
\hline 13 & 0.26 & 6.74 & $3,240,885$ & $21,843,565$ & $21,504,884$ \\
\hline 14 & 0.23 & 6.97 & $3,240,885$ & $22,588,968$ & $22,250,287$ \\
\hline 15 & 0.21 & 7.18 & $3,240,885$ & $\mathbf{2 3 , 2 6 9 , 5 5 4}$ & $\mathbf{2 2 , 5 9 2 , 1 9 2}$ \\
\hline \multicolumn{2}{|l|}{ Average Investment $N 338681$} & & & \\
\hline
\end{tabular}

Net Present Value (NPV) $=$ N22, 592,192

In Table 2, the average investment for postgraduate education of university lecturers in Edo and Delta States is $\$ 338$, 681, the cumulative cash inflow is $\$ 23,269,554$ while the NPV for all postgraduate programmes studied is $\$ 22,592,192$ and the profitability Index (PI) is 68.71. Table 1 has also shown that, it is highly economically viable to undertake postgraduate education in Nigerian Universities because postgraduate education has high positive cumulative net present value. This is further illustrated by Figure 1.

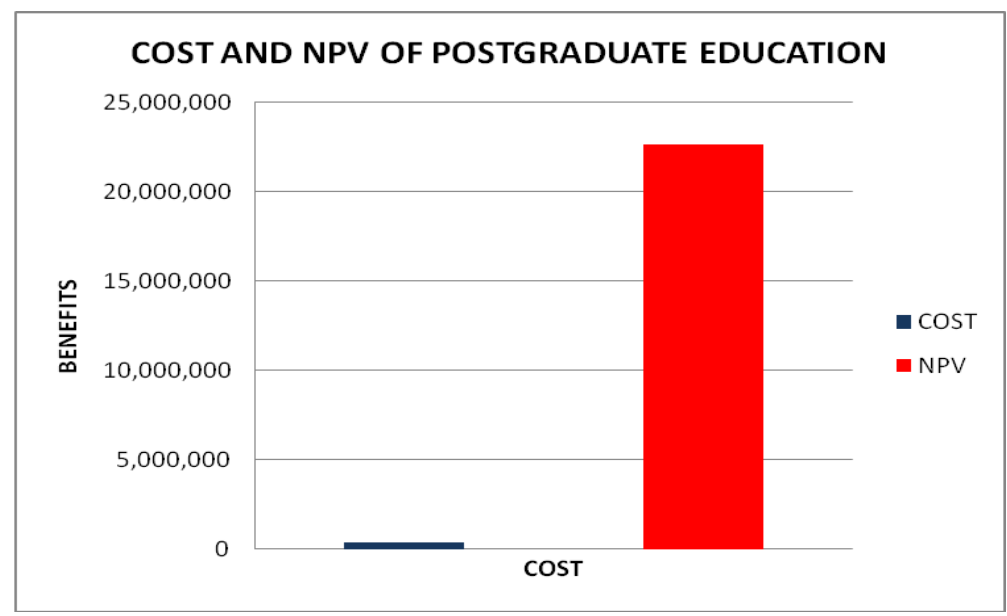

Figure 1: The cost and Net Present Value of Postgraduate education of University lecturers in Edo and Delta States.

\section{Question3}

Is there a variation in the economic benefits of postgraduate education of university lecturers in Edo and Delta States in Arts, Management science and science based courses?

Table 3: The Economic Benefits, Net Present value and the Profitability Index of Arts, Management Science and Science based courses.

\begin{tabular}{|c|c|c|c|}
\hline & Arts & Management science & Science \\
\hline Economic Benefit & $\cong 3,642,507$ & 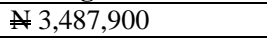 & $\approx 3,279,432$ \\
\hline Net Present Value & $\# 23,805,823$ & $\# 22,868,227$ & $\# 21,540,751$ \\
\hline Profitability Index & 59.04 & 72.50 & 83.41 \\
\hline
\end{tabular}

Source: Fieldwork

From data in table 3 , there are variations in the economic benefits of postgraduate education of university lecturers in Edo and Delta states. The economic benefit for Arts is \$3, 642,507, the Net Present Value is $\$ 23,805,823$ and the Profitability Index is 59.04. For Management Sciences the economic benefit is $\$ 3,487,900$, Net Present Value is $\$ 22,868,227$ and the Profitability Index is 72.50 and for Science the economic benefit is $\$ 3,279,432$ the Net Present Value is $\$ 21,540,751$ and the Profitability Index is 83.41 . It is economically viable for lecturers in Edo and Delta States University in all the courses to undertake postgraduate education in Nigerian Universities. In terms of profitability it is most profitable to undertake postgraduate education in the Sciences followed by management sciences and then Arts. 


\section{DISCUSSION OF FINDINGS}

This study revealed that postgraduate education is economically viable for university lecturers in Edo and Delta States. The average direct private unit cost for arts based courses is arts based courses is \$410,106 and average cash inflow for Arts based courses is $\$ 3,372,692$, the net present value is $\$ 23,805,820$ and the Profitability index is 59.09. For Science based courses the average investment is $\$ 261,399$ the average cash flow is $\$ 3,036,511$ net present value of cash flow $\$ 21,540,751$ and the profitability index 83.41 , for Management science based courses the average investment is $\$ 319,849$ the average cash flow is $\$ 3,229,537$, net present value $\$ 22,868,227$ and the profitability index is 72.5 . Comparing the results of the profitability Index of Arts based courses 59.09, Management Science courses 72.5 and Science courses 83.41 showed that it is highly profitable to undertake courses in the sciences. This agrees with the findings of Akangbou (1986) in his study on the economic returns to doctoral education. His findings was that doctoral education from the view point of the individual, in all disciplines are profitable and should be embarked upon.

In the study of Morikawa (2012), on postgraduate education and human capital productivity in Japan, the following findings were made: the average annual income was 5,238,000 yen and 6,777,000 yen for workers with undergraduate and postgraduate educations respectively. Focusing only on regular employees, the figures were $5,726,000$ yen and 7,119,000 yen for undergraduate and postgraduate educations, respectively, indicating that the average wage level of postgraduate workers was $24.3 \%$ higher than the wage level of undergraduate workers. This further agrees with this study that postgraduate education is profitable. In the United States (U.S) and the United Kingdom (U.K), Jaeger and Page (1996), according to Morikawa (2012), using the U.S. Population Survey data, found that postgraduate degrees are valued by the labour market. Specifically, masters' degree holders earn between 5.5\%-15.5\% more than B.Sc holders and Ph.D. degree holders earn between 8.3\%$10.3 \%$ more than holders of bachelor's degrees. Deere and Vesovic (2006) using data from the United States census, found that the hourly salary for workers with postgraduate educations was about $30 \%$ higher than the salary for workers with only college education in 2000. All these studies agree with the findings of this research that for the individual having a postgraduate education is economically beneficial.

\section{CONCLUSION AND RECOMMENDATIONS}

Based on the findings, it could be concluded that the direct private unit cost for postgraduate education of university lecturers in Edo and Delta states was $\$ 338,681$; the profitability index (PI) for all courses studied showed that it is economically viable to undertake postgraduate education. And finally it is most profitable to invest in science courses when we are faced with capital rationing. Therefore, Individuals should be encouraged to invest in postgraduate education because it is an economically viable project. Federal and State universities in Nigeria should introduce self-sponsored postgraduate programmes as a viable strategy for diversifying their sources of income because the individual benefits greatly from postgraduate education.

\section{REFERENCES}

[1]. Afzal M. (2011) Microeconometric analysis of Private returns to education and determinants of earnings. Pakistan Economic and Social Review Vol 49(1) p39-68

[2]. Akangbou, S. (1986) The economic returns to doctorate education: A case study.http://unilorin.edu.ng/journals/education/ije.

[3]. Rugar, T.O Ayodo, T.M.O \& Agak, J.O (2010) Rate of financial return to university schooling among lecturers in two public universities in Kenya. Educational Research and Reviewers 5(3) pp130-148.

[4]. Blundell, R., L. Dearden, A. Goodman and H. Reed (2000), The returns to higher education in Britain: Evidence from a British cohort. The Economic Journal, Vol 110, pp. F82-F99.

[5]. Central Bank Nigeria (2013) Statistical Year Book Deere, Donald R. \& Vesovic J. (2006), "Educational Wage Premiums and the U.S. Income Distribution: A Survey," in Eric A. Hanushek and Finis Welch eds. Handbook of the Economics of Education, Vol.1, Elsevier B.V., Ch. 6, pp. 255-306.

[6]. Jaeger, D. A. \& Page M.E (1996), Degrees Matter: New Evidence on Sheepskin Effects in the Returns to Education, Review of Economics and Statistics, 78 (4) pp. 733-740.

[7]. Morikawa, M (2012) Postgraduate Education and Human capital productivity in Japan. The research institute of Economy, Trade and industry (RIETI)

[8]. Psycharopoulos G. \& Patrimos H.A. (2004).Human Capital and Rates of Return. In The International Handbook on the Economics of Education, (Eds G. Johnes and J. Johnes) Cheltenham: Edward Elgar Publishing.

[9]. Olakulehin, F.K \& Panda, S.K (2012) Private cost of education: A comparative study of distance and campus-based university students in Nigeria. European journal of open, distance and E-learning.pp1-12

[10]. Nwadiani M.and Okafor C. J. (2015) An Analysis of the Direct Private Cost of Postgraduate Education Among University Lecturers in Edo and Delts States.Nigerian Journal of Educational Management. Deparment of Educational Manageemnt University of Benin, Benin City Vol1(1) pp 1-9. 